\title{
Analisis dan Pemanfaatan Unsur Belerang dan Salinitas Lumpur Bledug Kuwu di Desa Kuwu, Kecamatan Kradenan, Kabupaten Grobongan, Jawa Tengah \\ Sepridawati Siregara, Nora Idiawati Siregara,b
}

\author{
aProdi Geologi, FTM Institut Sains \& Teknologi AKPRIND Yogyakarta, \\ bProdi Kimia, FMIPA Universitas Tanjungpura Pontianak, \\ *Email : sepridawati_srg@yahoo.co.id
}

\begin{abstract}
Abstrak
This study was conducted to determine the levels of elemental sulfur and salinity of the mud Bledug Kuwu. The research area has a subsurface lithology bedding rock mud, sand stone and rocks submerged in saltwater, brackish water and sea water. Bledug Kuwu is a phenomenon of volcanic mud. Around Kuwu found several indications of an ancient sea that connect up to the east, that is to Cepu and westward to the region Boja and Cirebon. Judging from geological formations, estimated Kuwu to Cepu was once the sea. The ancient sea stretching from Bledug Kuwu region to the southwest that is to Sangiran and also to Boyolali. Bledug Kuwu mud has a high sulfur and salt contents, evidenced from the results of laboratory analysis where the average concentration of sulfur $62,883 \times 10^{2} \mathrm{mg} / \mathrm{Kg}$ with UV-vis spectrophotometry method and the average of salinity $57,15 \mathrm{mg} / \mathrm{L}$ by the Conductometry method. From the analysis, Bledug Kuwu mud can be used for tourism and an additional income for the local community. the mud of Bledug kuwu has high content of sulfur can be used as a treatment especially for skin diseases and salinity can be used for making salt.
\end{abstract}

Kata Kunci : Mud, Bledug Kuwu, Sulfur, Salinity

\section{Latar Belakang}

Bledug Kuwu adalah sebuah kawah lumpur (mud volcano) disertai dengan letupan-letupan gas dari dalam tanah yang berlangsung secara berkala antara 2 dan 3 menit, yang terletak di Desa Kuwu, Kecamatan Kradenan, Kabupaten Grobogan, Provinsi Jawa Tengah [4]. Pembentukan kawah lumpur (mud volcano) termasuk dalam tipe kolam lumpur panas dimana gas keluar dari suatu celah dengan temperatur lebih kecil dari titik didih [6]. Hal tersebut disebabkan oleh faktor pembentuk tenaga panasbumi atau geothermal secara umum diartikan sebagai manifestasi suhu bumi yang telah ada sejak bumi terbentuk [3].

Fenomena mud volcano di Bledug Kuwu berbeda dengan mud volcano di daerah lain. Di Bledug Kuwu terjadi karena proses alam [1]. Sedangkan di Porong Sidoarjo, mud volcano muncul karena proses pengeboran sumur eksploitasi [2].

Secara geologi, kawah lumpur Kuwu, sebagaimana kawah lumpur lainnya, adalah aktivitas pelepasan gas dari dalam teras bumi. Gas ini biasanya adalah metana. Kuwu adalah satu-satunya yang berlokasi di Jawa Tengah. Letupan-letupan lumpur yang terjadi biasanya membawa pula larutan kaya mineral dari bagian bawah lumpur ke atas diantaranya adalah sulfur dan garam dengan konsentrasi tinggi [5].

Tatanan geologi tersebut merupakan suatu kekhasan tersendiri yang dapat memberikan banyak manfaat bagi penghuninya. Oleh karena itu, perlu dilakukan analisis terhadap kadar belerang dan kadar garam dari lumpur Bledug Kuwu tersebut. Hasil yang telah didapatkan dari uji beberapa parameter tersebut dapat menjelaskan karakteristik dari lumpur Bledug Kuwu yang berada di desa Kuwu tersebut.

\section{Metodologi}

Metode penelitian yang digunakan dalam penelitian ini terdiri dari 3 bagian yaitu:

\subsection{Pendekatan Penelitian}

Dilakukan dengan cara meneliti secara langsung ke lapangan. Mengambil data geologi daerah Bledug Kuwu dan sekitarnya, mengukur langsung lumpur Bledug Kuwu dan pengambilan sampel lumpur Bledug Kuwu yang tidak dapat diukur langsung di lapangan atau hanya dapat diperiksa di LPPT UGM Yogyakarta, kemudian ditambah data dari data sekunder, yaitu data dari peneliti terdahulu, seperti data geologi, data geokimia yang dapat melengkapi data penelitian menjadi lebih lengkap.

\subsection{Obyek Penelitian}

Penelitian dilakukan di Bledug Kuwu, Desa Kuwu, Kecamatan Kradenan, Kabupaten Grobogan, Jawa Tengah. Lokasi Bledug Kuwu terletak pada koordinat $7^{\circ} 07^{\prime} 03.90^{\prime \prime}$ LS dan $111^{\circ} 07^{\prime} 17.61^{\prime \prime} \mathrm{BT}$, seperti yang terlihat pada gambar 1. 


\subsection{Tahapan Penelitian}

Penelitian lapangan dikerjakan untuk pengambilan sampel lumpur Bledug Kuwu yang terdiri dari 10 titik sampling yang berasal dari kawah dimana terjadi letupan-letupan yang berasal dari dalam tanah. Penentuan titik sampling ditentukan secara acak. Semua data tersebut direkam untuk dianalisis di laboratorium. Analisis yang langsung dilakukan di lapangan adalah suhu dan $\mathrm{pH}$ sedangkan Analisis laboratorium yang dilakukan adalah analisis unsur sulfur $(\mathrm{S})$ dan salinitas $(\mathrm{NaCl})$ dari lumpur Bledug Kuwu. Alat analisis yang digunakan adalah $\mathrm{pH}$ meter untuk mengukur suhu dan $\mathrm{pH}$, Spektrofotometer UV-vis untuk menentukan kadar sulfur (belerang) dan Konduktometer untuk menentukan salinitas $(\mathrm{NaCl})$ pada lumpur Bledug Kuwu.

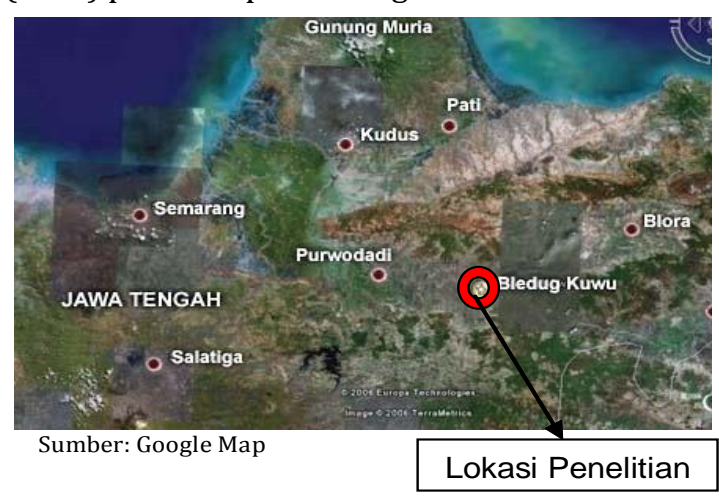

Gambar 1 Peta lokasi penelitian

\section{Hasil dan Pembahasan}

Secara geografis, Bledug Kuwu yang terletak di desa Kuwu berada dalam Kabupaten Grobogan yang merupakan lembah yang diapit oleh dua pegunungan kapur, yaitu Pegunungan Kendeng di bagian selatan dan Pegunungan Kapur Utara di bagian utara. Bagian tengah wilayahnya adalah dataran rendah. Dua sungai besar yang mengalir adalah Kali Serang dan Kali Lusi.

Sebagian besar wilayah terletak pada permukaan yang relatif datar dengan kemiringan kurang dari 5\%, daerah berbukit dan pegunungan terletak di bagian utara dan selatan, tepatnya di sekitar jalur pegunungan kendeng utara dan selatan.

Dari pengamatan di lapangan, terdapat 7 jenis batuan yang menjadi penyusun daerah Bledug Kuwu didasarkan pada bentang alam dan asosiasi batuan penyusunnya, yaitu paleosen fasies sedimen, paleosen fasies batu gamping, pleistosen fasies sedimen, miosen fasies batu gamping dan allumunium. Dari jenis batuan tersebut yang sebarannya merata adalah batuan allumunium dan paleosen fasies sedimen.
Sampel untuk penelitian ini diambil pada musim hujan. Besarnya diameter Bledug Kuwu bergantung pada musim. Pada musim hujan diameter melebar dan besar ledakan tidak tinggi. Letupan berasal dari tenaga endogen yang kuat dan ketinggian terkecil ialah $40 \mathrm{~cm}$. Pada musim kemarau diameter dan rongga menyempit, letupan agak lambat karena tanah mengkristal, dan ledakan tinggi, seperti yang terlihat pada gambar 2. Di sekitar lokasi hampir tidak terdapat tumbuhan dan hewan, hanya terdapat rumput pada pinggiran lokasi dan hewan yang datang pada sore hari ialah burung Blekok (Ardeola palloides).

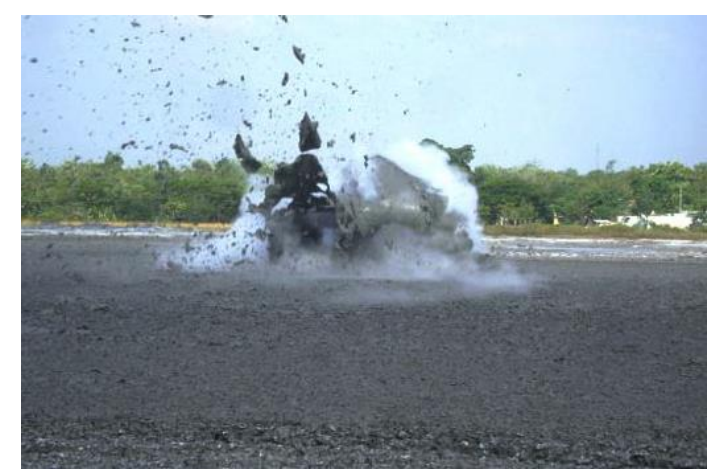

Gambar 2 Letupan Bledug Kuwu

Secara terperinci hasil analisis lumpur Bledug Kuwu tersebut dapat dilihat pada Tabel 1 dan 2 .

Tabel 1. Hasil analisis dilapangan

\begin{tabular}{ccc}
\hline Kode Sampel & Suhu( $\left.{ }^{\circ} \mathrm{C}\right)$ & $\mathrm{pH}$ \\
\hline Sampel 1 & 30 & 7,5 \\
Sampel 2 & 32 & 7,4 \\
Sampel 3 & 31 & 7,6 \\
Sampel 4 & 33 & 7,3 \\
Sampel 5 & 32 & 7,7 \\
Sampel 6 & 32 & 7,4 \\
Sampel 7 & 34 & 7,5 \\
Sampel 8 & 32 & 7,2 \\
Sampel 9 & 31 & 7,6 \\
Sampel 10 & 33 & 7,5 \\
\hline Rata-rata & 32 & 7,5 \\
\hline
\end{tabular}

Rata-rata suhu lumpur Bledug Kuwu di siang hari adalah $32^{\circ} \mathrm{C}$. hal ini menunjukan bahwa letupan-letupan yang terjadi tidak memiliki suhu yang tinggi walaupun menimbulkan asap putih. Rata-rata $\mathrm{pH}$ lumpur Bledug Kuwu di siang hari adalah 7,5. Hal ini menunjukan bahwa lumpur Bledug Kuwu memiliki pH basa (>7). 
Tabel 2. Hasil analisis laboratorium

\begin{tabular}{ccc}
\hline $\begin{array}{c}\text { Kode } \\
\text { Sampel }\end{array}$ & $\begin{array}{c}\text { Sulfur x } 10^{2} \\
(\mathrm{mg} / \mathrm{Kg})\end{array}$ & $\begin{array}{c}\mathrm{NaCl} \\
(\mathrm{mg} / \mathrm{L})\end{array}$ \\
\hline Sampel 1 & 53,998 & 45,35 \\
Sampel 2 & 54,523 & 49,40 \\
Sampel 3 & 53,336 & 47,62 \\
Sampel 4 & 70,771 & 51,55 \\
Sampel 5 & 60,542 & 60,37 \\
Sampel 6 & 65,443 & 70,32 \\
Sampel 7 & 75,032 & 65,45 \\
Sampel 8 & 50,890 & 50,32 \\
Sampel 9 & 80,387 & 55,78 \\
Sampel 10 & 63,908 & 75,36 \\
\hline Rata-rata & 62,883 & 57,15 \\
\hline
\end{tabular}

Rata-rata kandungan sulfur pada lumpur bledug Kuwu tersebut cukup tinggi yaitu 62,883 $\mathrm{x} 10^{2} \mathrm{mg} / \mathrm{Kg}$. Tingginya kandungan sulfur (belerang) pada lumpur Bledug Kuwu dipercaya memiliki khasiat untuk mengobati penyakit kulit dan dimanfaatkan oleh warga setempat maupun pendatang untuk mengobati penyakit tersebut. Karena Unsur ini terutama penting bagi manusia karena merupakan bagian dari asam amino metionin, sehingga mutlak diperlukan. Asam amino sistein juga mengandung belerang.

Rata-rata kandungan $\mathrm{NaCl}$ pada lumpur bledug Kuwu tersebut cukup tinggi yaitu 57,15 $\mathrm{mg} / \mathrm{L}$. Tingginya kandungan $\mathrm{NaCl}$ tersebut menunjukan proses terbentuknya Bledug Kuwu kemungkinan disebabkan karena adanya air laut yang terperangkap atau terjebak dalam sedimen batuan. Ada bermacam-macam cara air asin dapat bercampur dengan air permukaan di daerah delta dan pantai, salah satunya adalah connate water yaitu air yang terjebak dalam rongga-rongga batuan sedimen. Kemungkinan Bledug Kuwu juga terbentuk dari proses connate water karena mempunyai ciri-ciri yang hampir sama dengan laut yaitu airnya asin atau mengandung garam [5].

Kadar garam yang tinggi tersebut juga diperkirakan karena terjadinya peristiwa yang dinamakan intrusi air laut. Intrusi air laut merupakan suatu peristiwa penyusupan atau meresapnya air laut atau air asin ke dalam air tanah. Air tanah mengalir ke laut secara alami. Namun karena adanya pengambilan air tanah dalam jumlah yang besar, maka aliran air tanah yang menuju ke laut akan menurun bahkan sebaliknya, air laut akan merembes ke dalam sumur-sumur yang ada di daratan.

Intrusi air laut yang masuk ke dalam akuifer air tawar akan berpengaruh pada penurunan kualitas air tanah. Seberapa dampaknya, tergantung besarnya konsentrasi garam-garam yang terlarut.

\section{Kesimpulan}

Daerah penelitian merupakan sebuah fenomena gunung api lumpur (mud volcano) dengan gejala alam yang berupa letupan-letupan lumpur yang mengandung garam dan banyaknya kandungan gas serta mineral pada tanah, termasuk sulfur (belerang). Dari hasil analisis data geologi di lapangan, Bledug Kuwu termasuk dalam zona Randublatung dan proses terbentuknya, kemungkinan disebabkan karena adanya air laut yang terperangkap atau terjebak dalam sedimen batuan. Dari hasil analisis lumpur bledug Kuwu memiliki rata-rata suhu $32 \mathrm{oC}$, rata-rata $\mathrm{pH} 7,5$ dan konsentrasi rata-rata sulfur $62,883 \times 10^{2} \mathrm{mg} / \mathrm{Kg}$ serta salinitas 57,15 $\mathrm{mg} / \mathrm{L}$. Kandungan Sulfur dan Salinitas yang cukup tinggi tersebut dapat dimanfaatkan oleh masyarakat sebagai pengobatan dan sebagai bahan pembuat garam. Untuk kedepannya manfaat tersebut dapat lebih dimaksimalkan lagi.

\section{Daftar Pustaka}

[1] Atmiati, S., Aplikasi Metode Geolistrik Untuk Menentukan Intrusi Air Garam di Sekitar Bledug Kuwu Grobogan, Universitas Negeri Semarang, 2011.

[2] Davies, R.J., Brumm, M., Manga, M., Rubiandini, R., Swarbrick, R., Tingay, M., The East Java mud volcano (2006 to present): An earthquake or drilling trigger? Journal Earth and Planetary Science Letters . 272 (2008) 627-638, 2008.

[3] Ellis, A.J., \& Mahon, W.A.J., Chemistry and Geothermal System, Acade-mic Press, New York, 1977.

[4] Putra, G., Kabupaten Grobongan, Jawa Tengah, 2010.

[5] Rizqiya, F.U., Analisis Struktur Fraksi Fasa Kristal Natrium Klorida dari Brine Water Bledug Kuwu Sebagai Fungsi Waktu Kristalisasi Berdasarkan Pola Difraksi Sinar X (X Ray Diffraction). Skripsi, Yogyakarta: Program Studi Fisika Fakultas Sain dan Teknologi Universitas Islam Negeri Sunan Kalijaga, (2014).

[6] Samodra, H., Panas Bumi, Laboratorium Vulkanologi, Fakultas Teknik Geologi UPN Veteran Yogyakarta, 1984.

[7] Syahputra, B., Perancangan Trickling Filter Dengan Media Batu Apung Sebagai Upaya Penurunan Salinitas Air Payau (Studi Kasus Intrusi Air Laut Di Semarang). Jurnal Studi Lingkungan. 1(1): 47-56, 2009. 